\title{
Хранение семенного картофеля с использованием химических и физических методов воздействия на клубни
}

\section{С.В. Мальцев, Д.В. Абросимов, О.В. Абашкин}

Отражены результаты исследований влияния фитогормона этилена и гамма-облучения ${ }^{60} \mathrm{Co}$ на интенсивность прорастания семенных клубней картофеля, рост и развитие растений, число стеблей и клубней на куст, урожайность и структуру урожая. Обработка семенных клубней картофеля этиленом позволила увеличить общую урожайность картофеля в зависимости от сорта, района выращивания и применения орошения на 9,9-19,0\% (1,2-6,4 т/га).

Ключевые слова: картофель, фитогормон этилен, гамма-облучение, прорастание, стебли, урожайность.

$\mathrm{T}$ ехнологии хранения семенного картофеля, обеспечивающие рост урожайности этой с.-х. культуры, постоянно совершенствуются. Из химических методов воздействия в настоящее время перспективна обработка семенных клубней фитогормоном этиленом, а из физических - использование гамма-облучения.

Этилен - первый из обнаруженных газообразных растительных гормонов, обладающий очень широким спектром биологического действия. В сельском хозяйстве применяется уже довольно давно, однако при хранении семенного картофеля, эффективность его еще до конца не изучена [1]. Свободно диффундируя через ткани растений, этилен связывается со специальными рецепторами, присутствующими во всех клетках высших растений в мембране эндоплазматического ретикулума и аппарата Гольджи, и вызывает разнообразные биохимические реакции [2]. Известно, что кратковременное (72 часа) воздействие этилена (в диапазоне 0,02-20 мл/ $\mathrm{M}^{3}$ ) способствует выходу клубней из состояния ес-

тественного покоя и стимулирует начало их прорастания, а непрерывная экспозиция при длительном хранении картофеля, напротив, подавляет рост ростков [3]. Имеются сведения, что этилен способствует увеличению числа ростков, но при этом препятствует их росту в длину (элонгации) [4].

Двойственное влияние на растения картофеля имеют и ядерно-физические методы воздействия [5]. При высоких дозах достигается ингибирование прорастания клубней [6], при малых - проявляется эффект гормезиса. Суть этого явления состоит в стимулирующем действии умеренных доз радиации, которые приводят к ответу растения на стрессовый фактор, проявляющемуся в инициировании синтеза белка, активации соответствующих генов и репарации ДНК [7].

Цель исследований - изучить влияние химических и физических методов воздействия на семенные клубни при хранении картофеля и их последействие на накопление урожая.

\section{Методика}

исследований. Опыты по обработке этиленом се-

Таблица 1. Краткая характеристика погодных условий 2015-2017 годов

\begin{tabular}{|l|c|c|c|c|c|c|c|c|c|c|c|c|c|c|}
\hline \multirow{2}{*}{$\begin{array}{l}\text { Район } \\
\text { МО }\end{array}$} & \multicolumn{4}{|c|}{$\begin{array}{c}2015 \text { год } \\
\text { май }\end{array}$} & июнь & июль & август & май & июнь & июль & август & май & июнь & июль \\
\hline $\begin{array}{l}\text { Любе- } \\
\text { рецкий }\end{array}$ & ++ & + & - & -- & ++ & - & ++ & ++ & + & + & ++ & ++ \\
\hline $\begin{array}{l}\text { Озерс- } \\
\text { кий }\end{array}$ & ++ & + & ++ & -- & ++ & ++ & + & ++ & + & + & ++ & ++ \\
\hline
\end{tabular}

менного картофеля сортов различного срока созревания - Леди Клэр (ранний), Гала (среднеранний) и Сатурна (среднепоздний) проводили на базе хранилищ АО «Озеры» Озерского района Московской области. Газацию проводили по адаптированной к российским условиям технологии фирмы Restrain (т.e. при температуре $4{ }^{\circ} \mathrm{C}$ и со сроком экспозиции с ноября по конец апреля). За 3-5 дней до посадки подачу этилена прекращали. Для поддержания в хранилище постоянной заданной концентрации этилена (30 единиц по классификации Restrain) применяли газогенератор и газоанализатор. Картофель, обработанный этиленом, сажали в 2015-2017 годах в Московской области на экспериментальной базе «Коренево» в Люберецком районе (мелкоделяночный опыт, почва дерново-подзолистая супесчаная) и в Озерском районе на базе $\mathrm{AO}$ «Озеры» (производственный опыт на площади 40 га; почва дерново-подзолистая суглинистая), в том числе с применением орошения на основе дождевальной машины типа «Фрегат» (2-3 полива по 200 м³ га). В обоих районах технология выращивания была одинаковой на фоне минерального питания $\mathrm{N}_{60} \mathrm{P}_{120} \mathrm{~K}_{120}$ [8].

Гамма-облучение семенного картофеля сорта Леди Клэр (сетки массой по 10 кг в трехкратной повторности по каждому варианту) проводили в 2015-2017 годах в сентябре в ФГБНУ ВНИИРАЭ на установке ГУР120 (кобальт-60 ( $\left.{ }^{60} \mathrm{Co}\right)$, три варианта дозировок - 15, 25 и 50 Гр) с последующим хранением картофеля в холодильных камерах ФГБНУ ВНИИКХ при температурах 4 и $6^{\circ} \mathrm{C}$. Затем картофель сажали на экспериментальной базе «Коренево» (площадь полевого опыта $800 \mathrm{M}^{2}$ ).

Фенологические наблюдения, определение биометрических показателей, урожайности, математичес- 
кую обработку данных проводили по Б.А. Доспехову [9].

Результаты исследований. В полевом опыте рост и развитие растений в значительной степени определялся метеорологическими условиями периода вегетации, поэтому анализ эффективности использования этилена приводился в тесной взаимосвязи с метеорологическими условиями (табл. 1) отдельно по каждому году

Принятые условные обозначения температурно-влажностных параметров: «++» - очень благоприятные для роста и развития картофеля; «+» - благоприятные (несколько выше среднемноголетней нормы); «-» неблагоприятные (несколько ниже среднемноголетней нормы); «--» очень неблагоприятные (засуха).

Как известно, недостаток влаги при нахождении растений картофеля в фазе бутонизация - цветение не может быть компенсирован последующими осадками (так называемая критическая фаза развития) [10]. Наименее благоприятным для роста и развития растений картофеля по метеорологическим условиям оказался 2015 год, особенно в Люберецком районе, где в июле - августе наблюдалась засуха. В Озерском районе засуха наступила позже (только в августе), что с учетом большей влагоудерживающей способности суглинистой почвы по сравнению с супесчаной, позволи- ло растениям накопить значительно больший урожай.

Обработка семенных клубней картофеля этиленом в 2015 году способствовала увеличению количества наклюнувшихся глазков (главным образом за счет боковых при исключении апикального доминирования); более раннему появлению всходов (на 3-5 дней); растения были выше на 3-5 см; количество стеблей на куст оказалось выше (по сортам Леди Клэр, Гала и Сатурна соответственно на 20,0-22,4\%, 33,3-40,0\% и 16,3-22,2\%); фаза начала клубнеобразования наступила на несколько дней раньше и при этом количество клубней в пересчете на куст было больше на $11,8-31,9 \%$ в зависимости от сорта.

Таблица 2. Биометрические показатели и урожайность сортов картофеля в зависимости от изучаемых факторов, 2015-2017 годы (в среднем за три года)

\begin{tabular}{|c|c|c|c|c|c|}
\hline \multirow{2}{*}{$\begin{array}{c}\text { Район } \\
\text { выращивания }\end{array}$} & \multirow{2}{*}{$\begin{array}{c}\text { Вариант хранения семенных клубней и } \\
\text { применения орошения }\end{array}$} & \multirow{2}{*}{$\begin{array}{c}\text { Число стеблей, } \\
\text { шт/куст }\end{array}$} & \multirow{2}{*}{$\begin{array}{c}\text { Число клубней } \\
\text { шт/куст }\end{array}$} & \multicolumn{2}{|c|}{ Урожайность, т/га } \\
\hline & & & & общая & $\begin{array}{l}\text { товарная (клубни } \\
\text { фракции >50 мм) }\end{array}$ \\
\hline \multicolumn{6}{|c|}{ Леди Клэр (ранний) } \\
\hline \multirow{2}{*}{$\begin{array}{l}\text { Люберецкий } \\
\text { (супесчаная почва) }\end{array}$} & контроль & 5,1 & 10,0 & 23,8 & 18,9 \\
\hline & с этиленом & 6,1 & 11,7 & 27,7 & 23,5 \\
\hline $\mathrm{HCP}_{05}$ & & 0,3 & 0,5 & 0,8 & 0,6 \\
\hline \multirow{4}{*}{$\begin{array}{l}\text { Озёрский } \\
\text { (суглинистая почва) }\end{array}$} & контроль & 5,2 & 11,3 & 28,3 & 24,0 \\
\hline & с этиленом & 6,2 & 13,0 & 32,0 & 28,3 \\
\hline & контроль (орошение) & 5,3 & 12,3 & 32,4 & 28,8 \\
\hline & с этиленом (орошение) & 6,4 & 14,3 & 35,6 & 32,5 \\
\hline $\mathrm{HCP}_{05}$ & & 0,4 & 0,7 & 1,2 & 1,0 \\
\hline \multicolumn{6}{|c|}{ Гала (среднеранний) } \\
\hline \multirow{2}{*}{$\begin{array}{l}\text { Люберецкий } \\
\text { (супесчаная почва) }\end{array}$} & контроль & 5,4 & 17,4 & 23,9 & 19,1 \\
\hline & с этиленом & 7,2 & 21,2 & 27,3 & 22,2 \\
\hline $\mathrm{HCP}_{05}$ & & 0,3 & 0,6 & 0,8 & 0,6 \\
\hline \multirow{4}{*}{$\begin{array}{l}\text { Озёрский } \\
\text { (суглинистая почва) }\end{array}$} & контроль & 5,8 & 18,3 & 29,4 & 25,3 \\
\hline & с этиленом & 7,7 & 22,9 & 34,5 & 30,5 \\
\hline & контроль (орошение) & 6,3 & 19,2 & 33,9 & 30,4 \\
\hline & с этиленом (орошение) & 8,6 & 24,0 & 40,3 & 37,0 \\
\hline $\mathrm{HCP}_{05}$ & & 0,5 & 0,9 & 1,2 & 1,0 \\
\hline \multicolumn{6}{|c|}{ Сатурна (среднепоздний) } \\
\hline \multirow{2}{*}{$\begin{array}{l}\text { Люберецкий } \\
\text { (супесчаная почва) }\end{array}$} & контроль & 3,9 & 9,8 & 19,7 & 14,6 \\
\hline & с этиленом & 4,6 & 11,0 & 20,9 & 15,7 \\
\hline $\mathrm{HCP}_{05}$ & & 0,2 & 0,5 & 0,7 & 0,5 \\
\hline \multirow{4}{*}{$\begin{array}{l}\text { Озёрский } \\
\text { (суглинистая почва) }\end{array}$} & контроль & 4,1 & 10,6 & 23,3 & 19,3 \\
\hline & с этиленом & 5,0 & 12,2 & 25,9 & 22,0 \\
\hline & контроль (орошение) & 4,3 & 11,0 & 26,4 & 22,7 \\
\hline & с этиленом (орошение) & 5,2 & 13,0 & 30,0 & 26,7 \\
\hline $\mathrm{HCP}_{05}$ & & 0,4 & 0,6 & 1,2 & 1,0 \\
\hline
\end{tabular}



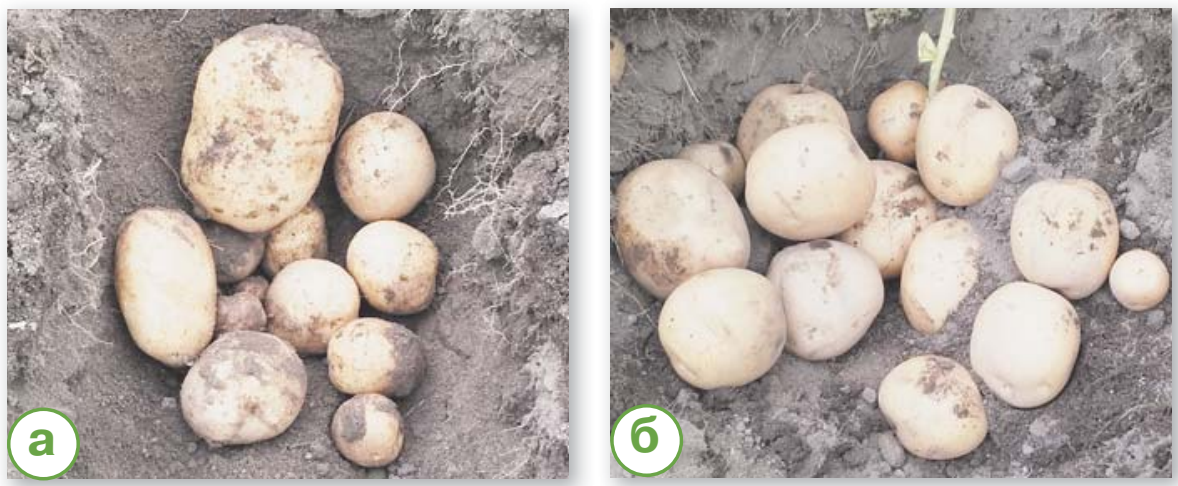

Рис. 1. Однородность урожая по структуре (на фотографиях клубни с одного куста (сорт Леди Клэр, 15.08.2015 год) при выращивании на дерново-подзолистой суглинистой почве Озёрского района Московской области: а) без применения этилена

(контроль); б) с применением этилена при хранении семенных клубней

В силу вышеперечисленных факторов, урожайность на вариантах с обработкой семенных клубней этиленом в 2015 году по этим сортам возросла в зависимости от района выращивания и применения орошения на 4,9-42,9\% или на 0,7-7,5 т/га по массе. Отмечена также более однородная структура урожая (рис. 1).

Выявленные закономерности особенно явно проявились в 2015 году на раннем сорте Леди Клэр при выращивании в Люберецком райо- не без орошения. В этих условиях прирост общей урожайности (а также в еще большей степени товарной урожайности, достигший величины 62,3\% или 7,6 т/га по массе) был обусловлен не только и не столько стимулирующим действием этилена на образование дополнительных клубней (за счет дополнительных стеблей), сколько смещением прохождения фенологических фаз развития на более ранние сроки, что при данных погодных условиях было кри- тически важным для накопления урожая вообще, и товарного урожая в особенности.

В более благоприятные и схожие по метеорологическим условиям 2016 и 2017 годы эффективность обработки семенных клубней этиленом в относительных цифрах была ниже, чем в 2015 году, однако по абсолютным значениям прирост урожайности находился на том же уровне (1,2-4,5 т/га в зависимости от сорта). Наиболее отзывчивым на применение этилена при благоприятных условиях выращивания (и в среднем за три года) оказался сорт Гала (табл. 2).

При исследовании физического метода воздействия на семенные клубни установлено, что гаммаоблучение в дозе 25 и особенно 50 Гр крайне отрицательно отразилось на их прорастании и урожайности картофеля в последействии независимо от температуры хранения 4 или $6{ }^{\circ} \mathrm{C}$ (вплоть до полного отсутствия всходов). Облучение клубней в дозе 15 Гр отрицательно влияло на урожайность картофеля только при температуре хранения $4{ }^{\circ} \mathrm{C}$ (снижение на 15\% по сравнению с контролем). Однако, при температуре хранения $6{ }^{\circ} \mathrm{C}$ разницы по всхожести,

\section{Контроль (без облучения)}
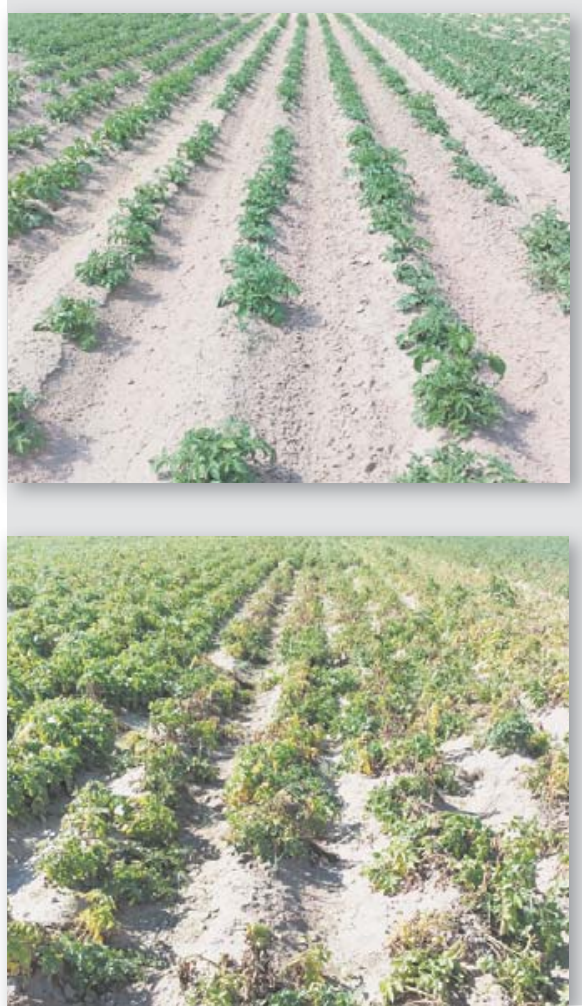

Гамма-облучение, 15 Гр
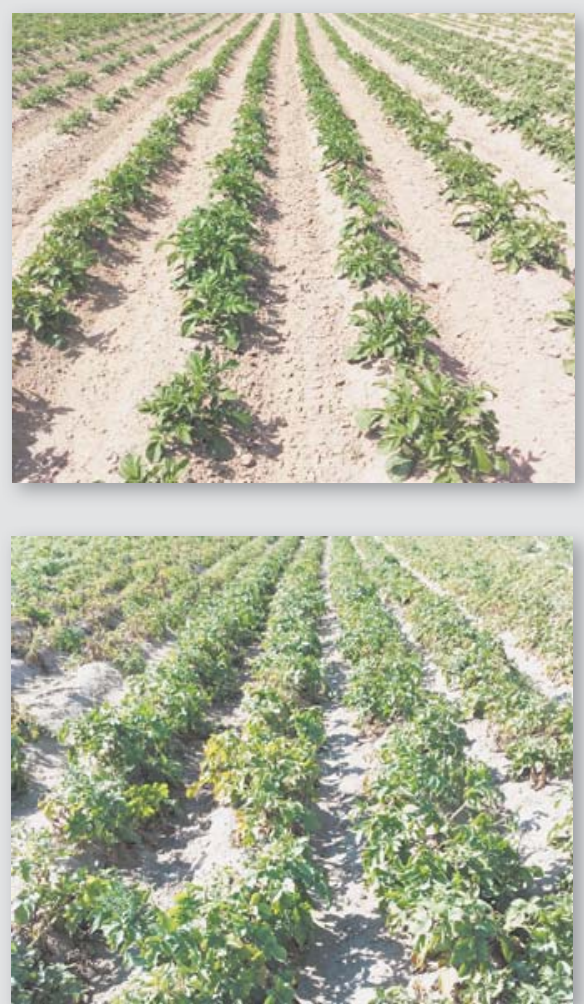

\section{Гамма-облучение, 25 Гр}
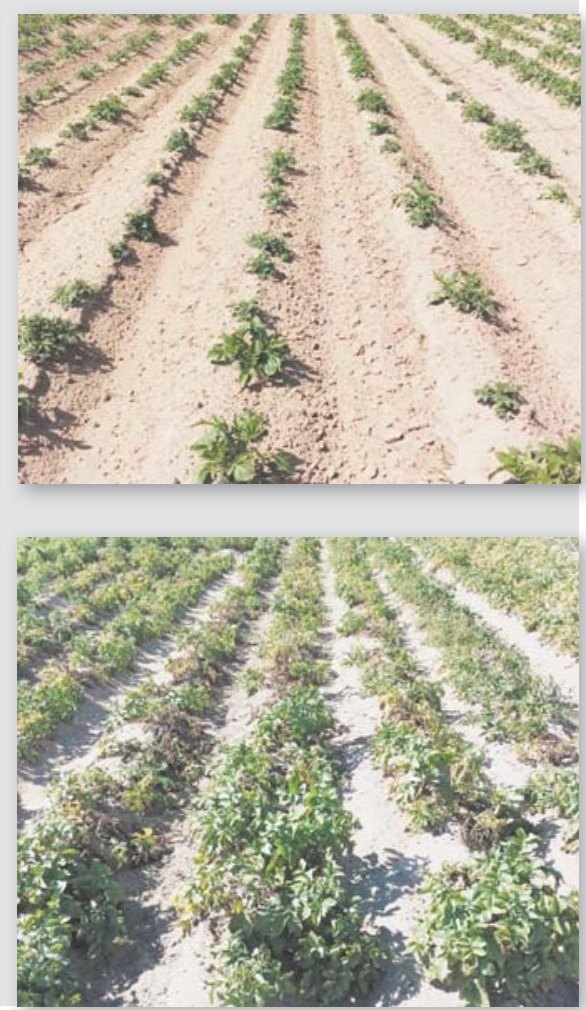

Рис. 2. Развитие растений картофеля сорта Леди Клэр на 36 (верхний ряд) и 88 день (нижний ряд) после посадки в зависимости от дозы гамма-облучения семенных клубней при температуре хранения $6{ }^{\circ} \mathrm{C}(Э Б$ «Коренёво») 
скорости прохождения фенологических фаз развития и урожайности в последействии облученного картофеля в сравнении с контролем в среднем за три года отмечено не было, но при этом более чем в два раза снижалась товарность урожая, (рис. 2).

Таким образом, гамма-облучение семенного картофеля, ввиду его сортоспецифичности по продолжительности периода естественного покоя и различной сортовой реакцией на применение одних и тех же доз облучения, представляется сомнительным и, во всяком случае, требует дальнейших исследований. Особенно с учетом дороговизны данного метода обработки (5-10 тыс. $\mathrm{p} / \mathrm{T})$ и слабо проработанной до настоящего времени нормативно-правовой базы, регламентирующей его применение.

\section{Выводы.}

1. Обработка семенных клубней картофеля этиленом при температуре хранения $4^{\circ} \mathrm{C}$ способствовала увеличению количества наклюнувшихся глазков; более раннему (на 3-5 дней) и дружному появлению всходов; образованию большего количества стеблей (на 19,9-36,0\%) и клубней (на 6,3-19,0\%) в пересчете на куст. Общая урожайность картофеля в зависимости от сорта, района выращивания и применения орошения возрастала на 9,9-19,0\% (1,2-6,4 т/га). Отмечена также более однородная структура урожая.
2. Гамма-облучение $\left({ }^{60} \mathrm{Co}\right)$ семенного картофеля в дозе 15 Гр сдерживало преждевременное прорастание клубней, однако урожайность и особенно уровень товарности в последействии сильно варьировали по годам исследований, так что в целом этот прием оказался неэффективным.

\section{Библиографический список}

1.Пшеченков К.А., Зейрук В.Н., Мальцев С.В. Период покоя клубней и определяющие его факторы // Защита и карантин растений. 2007. № 8. С. 54-55.

2.Ju C., Chang C. Advances in ethylene signaling: protein complexes at the endoplasmatic reticulum membrane // AoB Plants. 2012. pls031 (doi: 10.1093/aobpla/pls031).

3.Rylski I., Rappaport L., Pratt H.K. Dual effects of ethylene on potato dormancy and sprout growth // Plant Physiol. 1974. № 33. P. 638-662.

4.Wills R.B.H., Warton M.A. Effect of low levels of ethylene on sprouting of potatoes in storage // HortScience. 2004. № 39 (1). Р. 136-137.

5.Алексахин Р.М. и др. Перспективы использования радиационных технологий в агропромышленном комплексе Российской федерации // Вестник РАЕН. 2014. № 1. C. $78-85$.

6.Мальцев С.В., Пшеченков К.А. Обработка клубней ингибитором прорастания снижает потери при хранении // Картофель и овощи. 2009. № 1. С. 9.

7.Петин В.Г., Пронкевич М.Д. Радиационный гормезис при действии малых доз ионизирующего излучения. Обнинск: ИАТЭ НИЯУ МИФИ, 2013. 53 с.

8.Пшеченков К.А., Мальцев С.В. Технология посадки картофеля // Картофель и овощи. 2008. № 2. С. 9-10.

9.Доспехов Б.А. Методика полевого опыта (с основами статистической обработки результатов исследований). М., 1985. 351 с.

10.Мальцев С.В., Пшеченков К.А. Диагностика развития растений картофеля в период вегетации // Защита картофеля. 2011. № 2. С. 26-28.

\section{Об авторах}

Мальцев Станислав

Владимирович (ответственный за переписку), канд. с. -х. наук, с.н.с. группы хранения и переработки картофеля. E-mail: stanmalcev@yandex.ru. Абросимов Дмитрий Васильевич, канд. с. -х. наук, зав. лабораторией оригинального семеноводства

Абашкин Олег Владимирович, зав. лабораторией элитного семеноводства

ФГБНУ «Всероссийский научно-исследовательский институт картофельного хозяйства имени А.Г. Лорха»

Storage of seed potatoes using chemical and physical methods of influence on tubers

S.V. Maltsev (author for correspondence), PhD, senior research fellow of the group of potato storage and processing.

E-mail: stanmalcev@yandex.ru

D.V. Abrosimov, PhD, head of the original seed potato laboratory

O.V. Abashkin, head of the elite seed

potato laboratory

Lorch Potato Research Institute

Summary. The article reveals the results of studies the phytohormone ethylene and gamma-irradiation $\left({ }^{60} \mathrm{Co}\right)$ and its influence on seed germination, plant growth and development, number of stems and tubers per plant, yield and structure of yield. Treatment of seed potato tubers with ethylene allowed to increase the total yield of potatoes depending on the variety, area of cultivation and application of irrigation by 9.9-19.0\% (1.2-6.4t/ha).

Keywords: potato, phytohormone ethylene, gamma-irradiation, germination, stems, yield.

\section{В Рязанской области открывается картофелеперерабатывающий завод}

В селе Торбаево Касимовского района состоялось совещание по вопросу ввода в эксплуатацию картофелеперерабатывающего завода ООО «Касимовский картофель» и обеспечения его сырьем.

Совещание прошло под председательством заместителя министра сельского хозяйства и продовольствия региона Олега Иванникова с участием и.о. главы администрации Касимовского района Юрия Новикова, руководителей сельскохозяйственных организаций и фермеров, выращивающих картофель.

Олег Иванников доложил о посевных площадях, занятых под картофелем в регионе, перспективе их увеличения с учетом ввода новых перерабатывающих мощностей в ООО «Касимовский картофель».

Генеральный директор предприятия Валентин Савинов рассказал о планах по развитию производства в ООО «Касимовский картофель», знакомил руководителей сельхозпредприятий о сортах и характеристиках картофеля для производства «фри» и сухого картофельного пюре. В ходе совещания обсуждались вопросы сотрудничества картофелеводов с заводом по

\section{вопросам поставки}

переработки будущего урожая.

Участники семинара ознакомились с технологическим процессом переработки картофеля на заводе, осмотрели картофелехранилище, складские помещения для хранения готовой продукции и продегустировали готовую продукцию.

Производственные мощности предприятия по переработке картофеля составляют до 4 тыс. тонн сырья в месяц. Сейчаспредприятиеготовитсяксезонупереработки: отрабатывает процессы производства, разрабатывает ассортимент готовой продукции, прорабатывает вопросы реализации готовой продукции, активно готовится к сезону переработки картофеля нового урожая. 